\title{
Food allergy and anaphylaxis - 2047. Anaphylaxis to topically applied sodium fusidate on abrasions
}

Kangmo Ahn

From 2nd WAO International Scientific Conference (WISC 2012)

Hyderabad, India. 6-9 December 2012

\section{Background}

Fusidic acid is a bacteriostatic antibiotic that is effective primarily on gram-positive bacteria such as Staphylococcus species and Corynebacterium species. It is often used topically on skin, but also is given systemically as tablets or injections. Allergic contact dermatitis or urticaria has been reported as side effect of fusidic acid, but anaphylaxis to topically administered fusidic acid have not been reported yet.

\section{Methods}

Clinical history was throughly assessed, and oral challenge test was done to confirm the drug-induced anaphylaxis.

\section{Results}

A 16-year-old boy visited outpatient clinic due to further evaluation of anaphylaxis. He suffered abrasions on his arms during exercise and was treated with topical ointment containing sodium fusidate on the abrasions. Within 30 minutes, he developed urticaria and eyelid swelling, followed by cough and respiratory difficulty. His symptoms were relieved by emergency treatment in nearby hospital. In order to investigate the etiology, oral provocation with fusidate was performed. After $125 \mathrm{mg}$ (1/2 tablet) of sodium fusidate was administered, he developed cough and itching of the throat in $30 \mathrm{~min}$, followed by chest discomfort and urticaria. Forced expiratory volume in 1 second $\left(\mathrm{FEV}_{1}\right)$ dropped from $4.09 \mathrm{~L}$ at baseline to $3.50 \mathrm{~L}$ after challenge, although wheezing was not heard over his chest. After management with inhaled bronchodilator via nebulizer, chest discomfort was relieved and $\mathrm{FEV}_{1}$ rose to $3.86 \mathrm{~L}$.He was recommended not to use fusidate especially on the abrasions.

\footnotetext{
Pediatrics, Samsung Medical Center, Sungkyunkwan University, Seoul, South
} Korea

(c) 2013 Ahn; licensee BioMed Central Ltd. This is an Open Access article distributed under the terms of the Creative Commons Attribution License (http://creativecommons.org/licenses/by/2.0), which permits unrestricted use, distribution, and reproduction in any medium, provided the original work is properly cited.

\section{Conclusions}

Herein we report the first case of anaphylaxis by topical fusidic acid on the abrasions.

Published: 23 April 2013

doi:10.1186/1939-4551-6-S1-P132

Cite this article as: Ahn: Food allergy and anaphylaxis - 2047.

Anaphylaxis to topically applied sodium fusidate on abrasions. World

Allergy Organization Journal 2013 6(Suppl 1):P132.

Submit your next manuscript to BioMed Central and take full advantage of:

- Convenient online submission

- Thorough peer review

- No space constraints or color figure charges

- Immediate publication on acceptance

- Inclusion in PubMed, CAS, Scopus and Google Scholar

- Research which is freely available for redistribution 